\title{
The Impact of Servant Leadership on Employee Performance Mediated by Employee Loyalty and Employee Satisfaction: A Case Study of PT. Garuda Totalindo Jaya
}

\author{
Willy B. Wibowo ${ }^{1 *}$, Risa Bhinekawati ${ }^{2}$ \\ ${ }^{1}$ Sekolah Tinggi Manajemen IPMI, DKI Jakarta 12750, Indonesia \\ ${ }^{2}$ Sekolah Tinggi Ekonomi dan Perbankan Islam Mr. Sjafruddin Prawiranegara, DKI Jakarta 10560, \\ Indonesia
}

\begin{abstract}
A B S T R A C T
This study aims to investigate the relationships among the variables of servant leadership, employee loyalty, employee satisfaction, and employee performance in the context of a family business in Indonesia. This study applies quantitative approach with empirical evidence obtained from the entire employees of PT. Garuda Totalindo Jaya, a family-owned supplier spare part company as the case study. For the analysis technique, this study uses Partial Least Square (PLS) Structural Equation Modeling (SEM) as a program to run the collected data from 71 respondents during the period of July 2019. The findings of the study show that servant leadership has positive impact on employee loyalty and employee satisfaction; employee satisfaction has positive impact on employee loyalty; and employee loyalty has positive impact on employee performance. This study expands the knowledge on human resources in the context of family business in Indonesia. It should be beneficial for both researcher and also the company itself. Moreover, it can give another exposure of the future research to study more variables in term of leadership.
\end{abstract}

ART ICLE IN F O

Article History:

Received : 22-11-2019

Revised : 08-04-2020

Accepted : 19-11-2020

Published : 15-02-2021

Keywords:

Employee Loyalty

Employee Satisfaction

Employee Performance

Family Business

Servant Leadership

*Corresponding Author E-mail:

willy.wibowo@ipmi.ac.id

Copyright (C) 2021 Authors. This is an open access article distributed under the Creative Commons Attribution License (CC-BY-SA 4.0) which permits use, distribution and reproduction in any medium, provided the original work is properly cited \& ShareAlike terms followed.

\section{INTRODUCTION}

The roles of a leader as a game changer of a company include setting up the goals and target of work achievement; developing motivation, loyalty, and discipline of his subordinates; creating conducive work environment; giving encouragement; and supporting morale to the entire of the employees (Rivai, 2006). The roles of a leader as a game changer of a company include setting up the goals and target of work achievement; developing motivation, loyalty, and 
discipline of his subordinates; creating conducive work environment; giving encouragement; and supporting morale to the entire of the employees (Rivai, 2006).

In the context of family business, servant leadership is considered as an effective way in governing the business. Davis (2014) argues that servant leader in family business usually have strong principles and values that influence the strategy and ways of working of family businesses. He further suggests that servant leaders have abilities to treat their partners and followers equally and fairly while upholding high standard of achievement and aspirations for the groups (Davis, 2014). Indeed, leadership is the art of ability to influence human behavior and the ability to control people in the organization so that their behavior is in accordance with the desired behavior by the leader (Herujito, 2001). Leaders do not only represent position, but they need to possess leadership behavior and ability to influence others to become or to in-line with expected condition desired by the leaders to support achievement of company goals or targets (Herujito, 2001).

There are several sectors of industry were managed under family business management. From the total family business in Indonesia, the highest sector is manufacturing with a portion of $22 \%$ of the total number of family business in Indonesia, followed by energy, utilities \& mining at $9 \%$, food and drink $7 \%$, real estate \& renting $7 \%$, and on the least number of $6 \%$ are agriculture and financial services (PWC, 2018). The Price Waterhouse Cooper's report also reveals that family business can grow double digits in the upcoming two years by maintaining the best talent in the company is the key personal/business goals that can be considered. Accordingly, family business in manufacturing sectors contributes significantly to Indonesian economy compared to other industry.

Based on the above phenomena, the author conducted a research on the management of a family business in Indonesia, named PT. Garuda Totalindo Jaya, a spare part supplier company, hereinafter refer to Garuda Motor. Based on an interview with the owner, operating such growing company, roles of leadership will have significant influence on that company. The leader of Garuda Motor is required to have abilities to unite both people and job. Why this kind of ability required for this company is due to people expertise and employee hijacking issue. There are limited spare part supplier companies in Indonesia which means that the employee can easily hijacked by the competitor due to their expertise. On this point, Leaders should take employee loyalty and employee satisfaction into account. Based on the description above, the author was requested to investigate relationship between leadership, employee loyalty, employee satisfaction, and employee performance.

Based on the above phenomenon, there will be several points as objectives of this research in the context of family business in Indonesia. Firstly, to investigate the impact of Servant Leadership to Employee Loyalty and Employee Satisfaction; secondly, to investigate the impact of Employee Satisfaction to Employee Loyalty; thirdly, to investigate the impact of Employee Loyalty to Employee Performance.

The paper is a case study of Garuda Motor where the samples are limited to the employee of Garuda Motor which may cause the limitation of particular companies and the amount of the samples.

\section{LITERATURE REVIEW}

\section{Servant Leadership}

The basic concepts of the leadership, expand to the several of leadership style. One of the leadership style that was firstly presented by Greenleaf (1979) is the concept of servant leadership. $\mathrm{He}$ described a new leadership philosophy, one that advocates the servant as leader. To find out effective leadership, indepth research is needed to find out and identify the types of behavior needed to improve both individual performance and collective 
(Yukl, 2006). Servant leadership is one of the leadership styles that is highly recommended by some researchers who focus on leadership research (Sendjaya \& Sarros, 2002; Hale \& Fields, 2007; and Dierendonck, 2011). Servant leadership is an ethical, practical, and has a meaningful way of supporting a life that is led (Dierendonck, 2011).

Laub (1999) identified six main variables of the organization led by a servant leadership which are valuing people, developing people, building community, displaying authenticity, providing leadership, and sharing power. While others, Ehrhart (2004) identified seven dimensions in servant leadership, namely: forming relationships, empowering others, assisting the growth of followers, behaving ethically, demonstrating conceptual skills, placing followers first, and value others. The eight dimensions of servant leadership were also expressed by Dierendonck (2011), namely: standing back, forgiveness, courage, empowerment, accountability, authenticity, humility, and stewardship.

Servant leadership put employee serviceoriented in the first place with focusing on employee development while achieving the company's goals. Bringing this spirit into the work environment, have a positive impact on employees' psychological. Employees feel that they are part of the organization and feel trusted by the company. Once employees feel comfortable with the condition, automatically it will impact or even improves their loyalty. Furthermore, employee satisfaction also increases due to the leader giving attention to their needs. The more the company fulfilling employee's needs, the more satisfaction received from them (Ding et al., 2012).

Servant leadership is one of the leadership styles that put the leader orientation on his/ her subordinates to provide services. That kind of treatment by the leader creates environment that employees can work without any pressure and warm working environment. In result, employees will give extra miles on their work station to perform as expected by the organization (Setyaningrum et. al., 2017).

From the explanation above, we can conclude some point on that. Servant leadership is one of the leadership styles that might be most suitable with the companies which put the value of their employee as priorities. Core of servant leadership is always put the employee development as main purpose to achieve the target. There are several researches conducted to explore on servant leadership and found that all of researcher has different opinion on the dimension of servant leadership, means that research about servant leadership is interesting to be explored.

\section{Employee Loyalty}

In general, loyalty can be interpreted by as service and trust given or directed to someone or institution in which there is a sense of love and responsibility to try to provide the best service and behavior (Rasimin, 1998). Loyalty can also described as a form of loyal attitude of a person particularly in non-physical form such as thought and attention. (Reichheld \& Teal, 1996). Another understanding of loyalty has been also expressed by Pandey \& Khare (2012). According to them, loyalty can be described as self-service of the employee concerned for a company because they believe that this is the best choice for them in order to achieve the company goals. Briefly, Ding et al. (2012) stated that employee loyalty is the attitude of employees towards the community. The researcher believes that the loyalty of both employees and customers play an important role in the continuity of a company business and its future development. Therefore, both of these are equally important (Wang et al., 2009).

Steers \& Porter (1983) suggest aspects that can support loyalty related to the attitude that will be carried out by employees and is a psychological process of creating loyalty in the company. Another researcher Siswanto (2003) revealed that aspects of loyalty in the work carried out by employees are obeying the rules, responsibility, and work attitude. According to Simamora (1995), there are three basic reasons 
for employee loyalty, such as: rational factor, emotional factor, spiritual factor.

In sum, there are several aspects that can support employee loyalty such as desire to be part of the company family, desire to give the best effort to the company, as well as trust and understand the company's value. Other aspects that identified employee loyalty include obedience to the rules, being responsible, and work attitude. It is also noted that there are several reasons as the background reason employee need to be loyal such as Rational Factor, Emotional Factor, and Spiritual Factor.

\section{Employee Satisfaction}

Employee Satisfaction, often also referred to as job satisfaction, is one of the topics most often discussed by those who work in an organization or company. According to Vroom (1964), employee satisfaction is considered as a perception or emotional reaction from an employee to important aspects of his work that are faced daily. Employee Satisfaction can also be interpreted as a condition where the assessment of one's work or work experience results in a pleasant or positive emotional state (Locke, 1976). The following theories discuss the origin of employee satisfaction according to Maslow, Herzberg, Vroom, and Adams. Four theories that are often used, namely: Maslow's hierarchy of needs theory, Herzberg's two-factor theory, Expectancy Theory of Vroom, and Equity Theory of Adams.

In 1943, Maslow introduced a theory related to employee satisfaction which is widely used in many fields. This theory uses psychological aspect and called Maslow's hierarchy of needs theory. In the study of Nguyen (2016), Maslow's Theory categorizes hierarchy of needs into five levels in ascending order: physiological, safety, love/ belonging, esteem and self-actualization.

Among existing theories, the next theory related to employee satisfaction is Herzberg, Mausner, \& Snyderman (1993). This theory was applied by Herzberg to 200 accountants and engineers to identify the factors that support satisfaction and dissatisfaction of the workers. The study found that the factors associated with employee satisfaction or called intrinsic factors are: achievements, responsibility, recognition, work itself, advancement, and growth. While the factors related to employee dissatisfaction or called extrinsic factors are: organizational policies, working conditions, supervision, salary, interpersonal relations, status, and security.

Expectancy theory of Vroom (1964), states that all conditions including work motivation and employee behavior are not determined by current reality conditions but are determined by employee expectations of future conditions. The theory emphasizes that the expectation of future conditions is a determinant of employee satisfaction.

In the Equity Theory of Adams (1965) it is stated that the tendency of employee to judge and weigh are the two main things in this theory. Employee will tend to define fairness by comparing the effort that they put in with what they will get and will compare ratio with other employees who are in the same scope of work as them.

\section{Employee Performance}

One of the factors that influence the success of a company is individual employee performance. From this basis, many companies give their main focus to improve the performance of their employees. Performance problems are always a difficult challenge to conquer. If management is focused in this challenge, they need information related to the factors that influence employee performance improvement. One of the performance measures used to measure employee performance is the intellectual ability supported by ability to manage themselves and the ability to build relationships with others (Martin, 2000).

Performance is the result of certain activities in a specified period of time or the production of a specific job (Gomes, 2001). Performance is also said as a systematic evaluation of the work carried out by employees and a potential to be developed (Masrukhin \& Waridin, 2006). Other researchers 
said that performance is a universal concept of measuring the operational effectiveness of a company, or certain parts of the company and predetermined employee operational standards (Siagian, 2003). Mangkunegara (2005) stated that performance is the quality and quantity achieved by an employee to perform tasks in accordance with the responsibilities given.

As conclusion, employee performance is result of several standards and target set by the company or department of the company at the specific time in order to achieve the company goals.

Based on the previous researches and also theory as described above, explaining on relationship between servant leadership, employee loyalty, employee satisfaction, and employee performance, the framework theory in this research is described as follows:

\section{Hypothesis Development}

Jaramillo et al. (2009) concluded the results of his study that servant leadership behavior will initially increase employee adaptation to the company, increase employee commitment to the company and ultimately will reduce employee resignation rates. The same conclusion also mentioned by Ding et al. (2012), said that servant leadership will effect on increasing of employee loyalty, and with increasing employee loyalty, it will reduce the level of turnover. The same thing related to servant leadership influences employee loyalty was also expressed by Hashim (2014), employees will increase their loyalty as they adapt to their work environment, this is due to the pattern of leaders serving their employees. Furthermore, Liden et al. (2008) also stated that servant leadership creating positive working environment. This condition brings the employee to feel comfortable and also resulted to employee loyalty. Based on the explanation above, it can be hypothesized that:

H1: Servant leadership has a positive impact on employee loyalty

Weiss (2004) concluded that servant leadership is important and effective on many aspects. This is because serving leadership concentrates heavily on the needs of the employees, on their emotions and their happiness. Therefore, servant leadership is very influential on their happiness and satisfaction. Another statement also mentioned that the effect of the leadership may impact to the employee satisfaction and also employee performance toward the achievement of company goal (Benligiray, 2004). Jenkins \& Stewart (2008) revealed in their research in India,

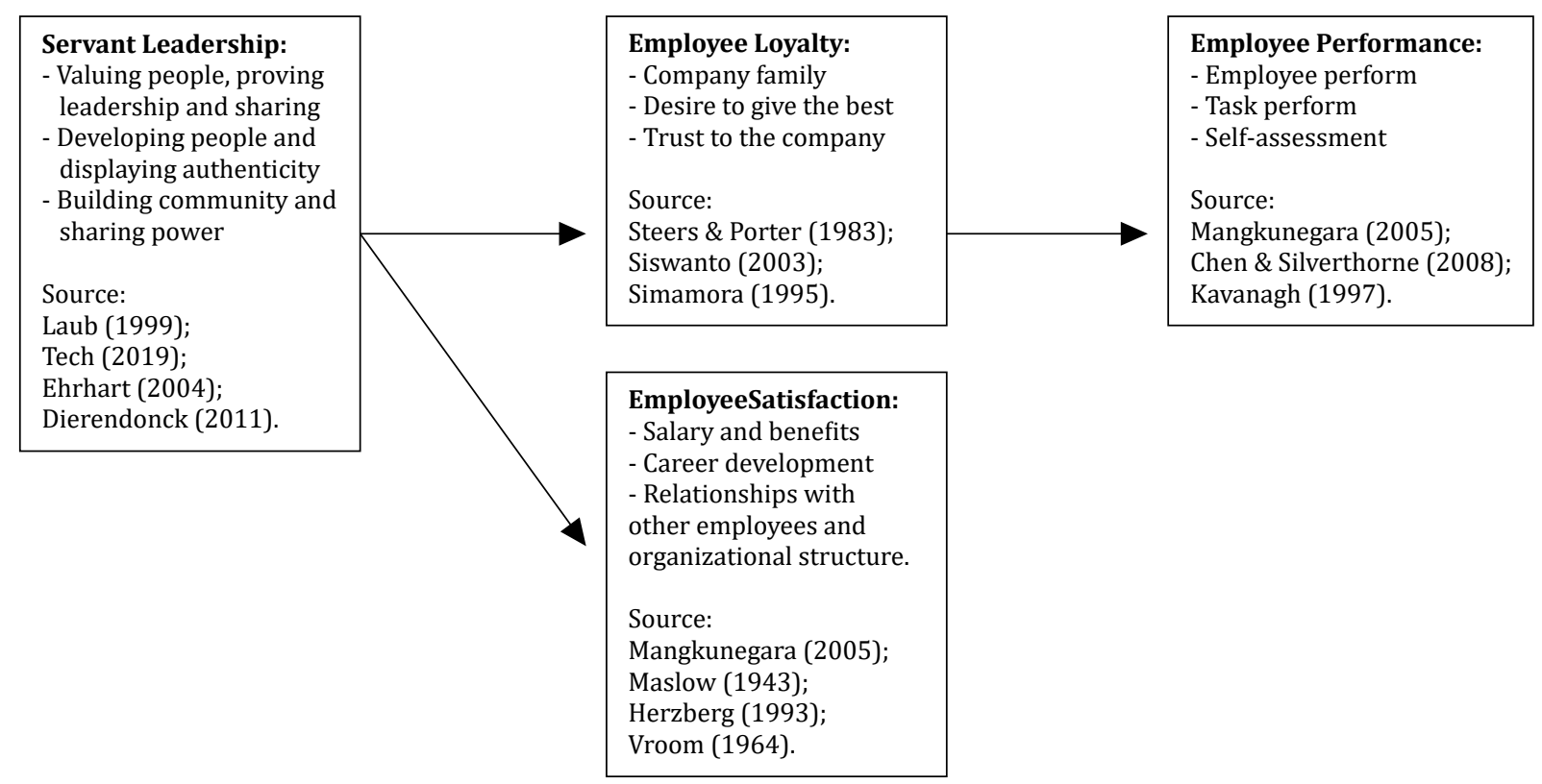

Figure 1. Theoretical Framework 
it shows that the higher the services provided by leaders, the more satisfaction is obtained by employees. Similar result about the influence of servant leadership has a positive influence on employee satisfaction is also expressed in Mehta \& Pillay (2011) research. Based on the explanation above, the following hypothesis can be developed:

H2: Servant leadership has a positive impact on employee satisfactio

Tang Yao et al. (2008) analyzed from two different perspectives about employee satisfaction affects to employee loyalty. The first approach is related to the risks that will be perceived by employees. Employees are more likely to choose to remain in the current company rather than move to a new unfamiliar to minimize the risk. The second approach is positive emotions. Employees will bring positive energy if they feel satisfied, calm, and ultimately work well. From the above explanation, it concludes that employees who are satisfied will tend to continue working in the current company. The same conclusion is also reflected in the results of other studies (Chee et al., 2007; Falkenburg \& Schyns, 2007; Alfonso \& Sousa-Poza, 2007). The study shows that when employee satisfaction is low, the turnover rate increases. Based on the explanation above, the following hypothesis can be formulated:

H3: Employee satisfaction has a positive impact on employee loyalty

Niehoff et al. (2001) have defined loyalty as active behaviors that demonstrate pride in and support for the organization. Defending the organization against criticism, emphasizing the positive aspects of the organization, and refraining from complaining about the organization would be examples of such behaviors. Loyal employees will contribute a lot to the company. They will give extra miles to every responsibility they have and also act as company representatives for activities outside the company. In this case, loyal employees will make a good contribution to the company and help the company work efficiently (O'Reilly \& Chatman, 1986). Based on the explanation above, can be hypothesized:

H4: Employee loyalty has a positive impact on employee performance

Based on the above hypothesis, a conceptual framework can be drawn up in Figure 2.

\section{METHODS}

Quantitative research methods were chosen in this study because by using this approach, researchers hope to be able to explain the relationship between the chosen variables and be able to analyze the causal effects caused by these variables logically. Arghode (2012) explained that by using quantitative methods, researchers can explain social behavior by emphasizing the measurement and causal analysis of variables that exist in a logical framework. To find findings that are broad, nonabstract, and generalizable and can be presented briefly, then quantitative research methods will be appropriate (Hagan, 2014).

This study is a causal study between selected variables. Silalahi (2009) explained that causal research is a study that focuses on the causal relationship between two or more of the existing variables, so that it can explain the effect of changes in the variation of values in a variable

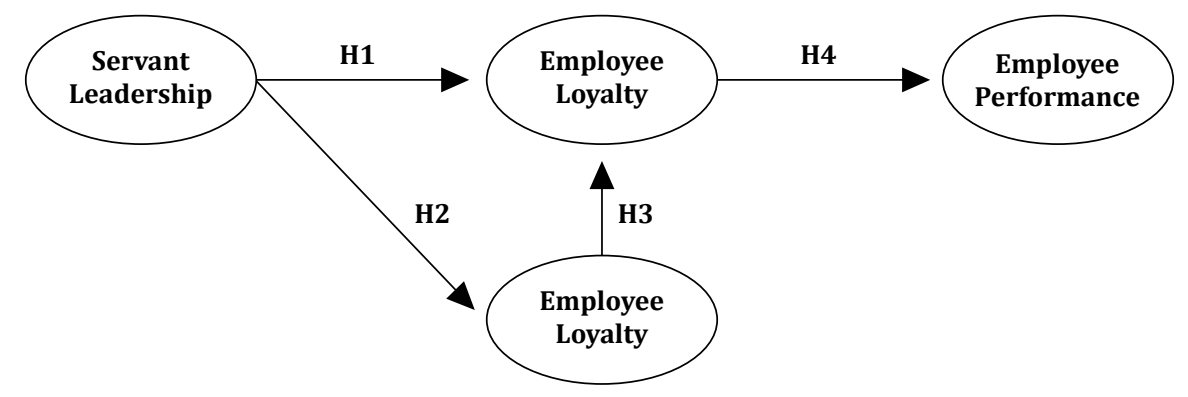

Figure 2. Conceptual Framework 
against other variables. Considering the purpose of the research and also explained by existing theories, quantitative method was appropriate for this research to apply a likert-type survey instrument to measure participants' perspectives to identify a general pattern of reactions to closedended statements.

Population is the total number of units or elements to be investigated by the author, in this case can be in the form of an organism, person or group of people, communities, organizations, objects, events, or reports which each has a characteristic and must be defined specifically and focused (Silalahi, 2009). In this case, study was taken in a spare parts company called Garuda Motor in the Jakarta area, thus the population taken is all employees in the company.

Silalahi (2009) stated sample is as part of a population that has attributes as a whole population or each part of the population itself is chosen based on its level of representation. In this case study, sample was taken from the entire of the population itself means entire employee of Garuda Motor. Total target respondent of the employee of Garuda Motor is about eighty employees (80). Thus, all the 80 employees were given questionnaires and 71 responded, representing about $89 \%$ of the population. And the other 9 (19\%) employees were not in place and some of them are not categorized as respondent.

There are four variables used in this study. Servant leadership is placed as the first variable or independent variable in this study. As mediating variables there are two variables which are employee loyalty and employee satisfaction. And the last variable or dependent variable is employee performance.

According to Ghozali (2014), Structural Equation Modeling (SEM) is an evolution of multiple equation models developed from the principle of econometrics and combined with the organizing principles of psychology and sociology, SEM has emerged as an integral part of academic managerial research. Based on the above concerned and in order to analyze the effect model between the selected variables, independent variable and the dependent variable, the SEM_PLS method was chosen in this case study.

To use the PLS-SEM method, the authors adapted the composition structure recommended by Ghozali (2014). The composition structure in this study consists of reliability evaluation, data validity evaluation, path coefficient \& coefficient of determination test, and also bootstrapping method to investigate t-statistics value, which will be used to test the hypothesis.

\section{RESULTS}

For quantitative approach, total respondents for quantitative data are 71 employees of PT. Garuda Totalindo Jaya in the majority of male as much as $72 \%$ of the total number of existing employees. The age distribution of employees is at the age of 17 to 25 years by taking a portion of $49 \%$ of the total employees. On the second and third place with a balanced number of people aged 26 years old to 35 years old by $25 \%$ and aged 36 years old to 45 years old by $21 \%$.

In terms of education background, the average employee is a senior high school graduate as much as $73 \%$ of total employees and the rest of the population has educational background varies from elementary school until bachelor degree. As many as $34 \%$ of employees have worked for 2 to 5 years of service, $27 \%$ of employees are classified as new employees, within 6 months to 1 year of service, and $23 \%$ of employees have worked for 6 to 10 years. From the entire employees, there are only $6 \%$ who hold functional positions as supervisors and the remaining $94 \%$ are staff. The figure below will show the portion of each profile of the employee.

\section{Quantitative Approach Result}

As mentioned previously that reliability and validity test should be evaluated for this study. Permissible loading factor for convergent validity is 0.5 . If the loading factor value $>0.5$ then the 
Willy B. Wibowo, Risa Bhinekawati / The Impact of Servant Leadership on Employee Performance Mediated by Employee Loyalty and Employee Satisfaction: A Case Study of PT. Garuda Totalindo Jaya / 18 - 31

convergent validity is fulfilled, if the loading factor value $<0.5$ then the construct must be excluded from the analysis (Ghozali, 2014). The result revealed that all loading factors of each indicator show a number above 0.5 which means it is above the prerequisite loading factor. It can be concluded that the entire data collected meets the convergent validity test criteria.

Table 1. Convergent Validity

\begin{tabular}{lcc}
\hline Name of Variable & Indicator & Loading Factor \\
\hline Servant leadership & Sl1 & 0.833 \\
\cline { 2 - 3 } & SL2 & 0.932 \\
\cline { 2 - 3 } & SL3 & 0.926 \\
\hline Employee Loyalty & EL1 & 0.820 \\
\cline { 2 - 3 } & EL2 & 0.823 \\
\hline Employee Satisfaction & EL3 & 0.747 \\
\cline { 2 - 3 } & ES1 & 0.835 \\
\cline { 2 - 3 } & ES2 & 0.875 \\
\hline Employee Performance & ES3 & 0.710 \\
\cline { 2 - 3 } & EP1 & 0.671 \\
\cline { 2 - 3 } & EP2 & 0.929 \\
\hline
\end{tabular}

The construct considered as a good construct if the Average Variance Extracted (AVE) value is above 0.5 (Ghozali, 2014). The entire AVE for each variable have the value higher than minimum required value 0.5 , hence for the result for construct validity considered as a good construct which can be seen in table 2 .

The cross-loading value of each indicator included in one variable must have a greater value than the value of the cross-loading indicator in the other latent variable. If this condition is fulfilled, it means that each latent variable has good discriminant validity (Ghozali, 2014). The result in table 3 shows that all indicators in one variable have greater value compared with cross-loading indicators in the other latent variable, thus the condition is fulfilled and categorized each latent variable has good discriminant validity.

Table 2. Construct Validity

\begin{tabular}{lc}
\hline Variable & AVE \\
\hline Servant Leadership & 0.807 \\
\hline Employee Loyalty & 0.636 \\
\hline Employee Satisfaction & 0.656 \\
\hline Employee Performance & 0.693 \\
\hline
\end{tabular}

The reliability of a construct needs to be tested in a study. The test carried out is internal reliability and construct reliability. Two parameters that can be used are Cronbach's Alpha and Composite Reliability. The minimum value used as a parameter is 0.7 (Ghozali, 2014). From the result shown on the table 4 , we can conclude that both internal reliability and construct reliability considered reliable.

Table 4. Internal and Construct Reliability

\begin{tabular}{lcc}
\hline $\begin{array}{l}\text { Name of } \\
\text { Variable }\end{array}$ & $\begin{array}{c}\text { Cronbach's } \\
\text { Alpha }\end{array}$ & $\begin{array}{c}\text { Composite } \\
\text { Reliability }\end{array}$ \\
\hline Servant Leadership & 0.880 & 0.926 \\
\hline Employee Loyalty & 0.713 & 0.840 \\
\hline Employee Satisfaction & 0.736 & 0.850 \\
\hline Employee Performance & 0.768 & 0.869 \\
\hline
\end{tabular}

Table 3. Discriminant Validity

\begin{tabular}{lcccc}
\hline & Servant Leadership & Employee Loyalty & Employee Satisfaction & Employee Performance \\
\hline Sl1 & $\mathbf{0 . 8 3 3}$ & 0.360 & 0.370 & 0.310 \\
\hline SL2 & $\mathbf{0 . 9 3 2}$ & 0.426 & 0.461 & 0.375 \\
\hline SL3 & $\mathbf{0 . 9 2 6}$ & 0.542 & 0.456 & 0.386 \\
\hline EL1 & 0.509 & $\mathbf{0 . 8 2 0}$ & 0.558 & 0.536 \\
\hline EL2 & 0.368 & $\mathbf{0 . 8 2 3}$ & 0.523 & 0.507 \\
\hline EL3 & 0.316 & $\mathbf{0 . 7 4 7}$ & $\mathbf{0 . 8 3 5}$ & 0.498 \\
\hline ES1 & 0.433 & 0.591 & $\mathbf{0 . 8 7 5}$ & 0.569 \\
\hline ES2 & 0.441 & 0.615 & $\mathbf{0 . 7 1 0}$ & 0.703 \\
\hline ES3 & 0.273 & 0.486 & 0.503 & $\mathbf{0 . 6 7 1}$ \\
\hline EP1 & 0.492 & 0.487 & 0.675 & $\mathbf{0 . 9 2 9}$ \\
\hline EP2 & 0.318 & 0.660 & 0.582 & $\mathbf{0 . 8 7 5}$ \\
\hline Ep3 & 0.217 & 0.555 & & \\
\hline
\end{tabular}


Since all constructs are reliable and valid, the research model can be used to test the formulated hypothesis. By using the SEM-PLS method, tests on structural models have been carried out to see the coefficient of determination and path coefficient. After knowing the significant correlation of variables to other variables, the bootstrapping method is carried out to test the predetermined hypothesis.

SEM-PLS method was used on the study to test the structural models, to see the coefficient of determination and path coefficient. This procedure was conducted to see the correlation significance between defined variables.

After knowing the correlation between variables, bootstrapping method was conducted to test the predefined hypothesis.

To described coefficient of determination, each of determination coefficient value of variables multiplied by $100 \%$. Employee loyalties produce determination coefficient value at $52.5 \%$ which consider as moderate. Such value shows that $52.5 \%$ of the variation in employee loyalty can be explained by servant leadership and employee satisfaction, while the remaining value of $47.5 \%$ can be explained by other variables outside this research.

On the variable of employee satisfaction, coefficient of determination produces a value of 23.1\% and considered weak. From such value shows that only $23.1 \%$ of variation in employee satisfaction can explain by servant leadership, while the other remaining $76.9 \%$ of variation is explained by other variable outside this research.

On the dependent variable of employee performance, it is shown that coefficient of determination produces value of $47.3 \%$ and considered as weak. This determination coefficient value shows that $47.3 \%$ of variation in employee performance is explained by employee loyalty, while remaining $52.7 \%$ is explained by other variable outside this research.

Table 5. R-Square

\begin{tabular}{lc}
\hline Name of Variable & AVE \\
\hline Employee Loyalty & 0,525 \\
\hline Employee Satisfaction & 0,231 \\
\hline Employee Performance & 0,473 \\
\hline
\end{tabular}

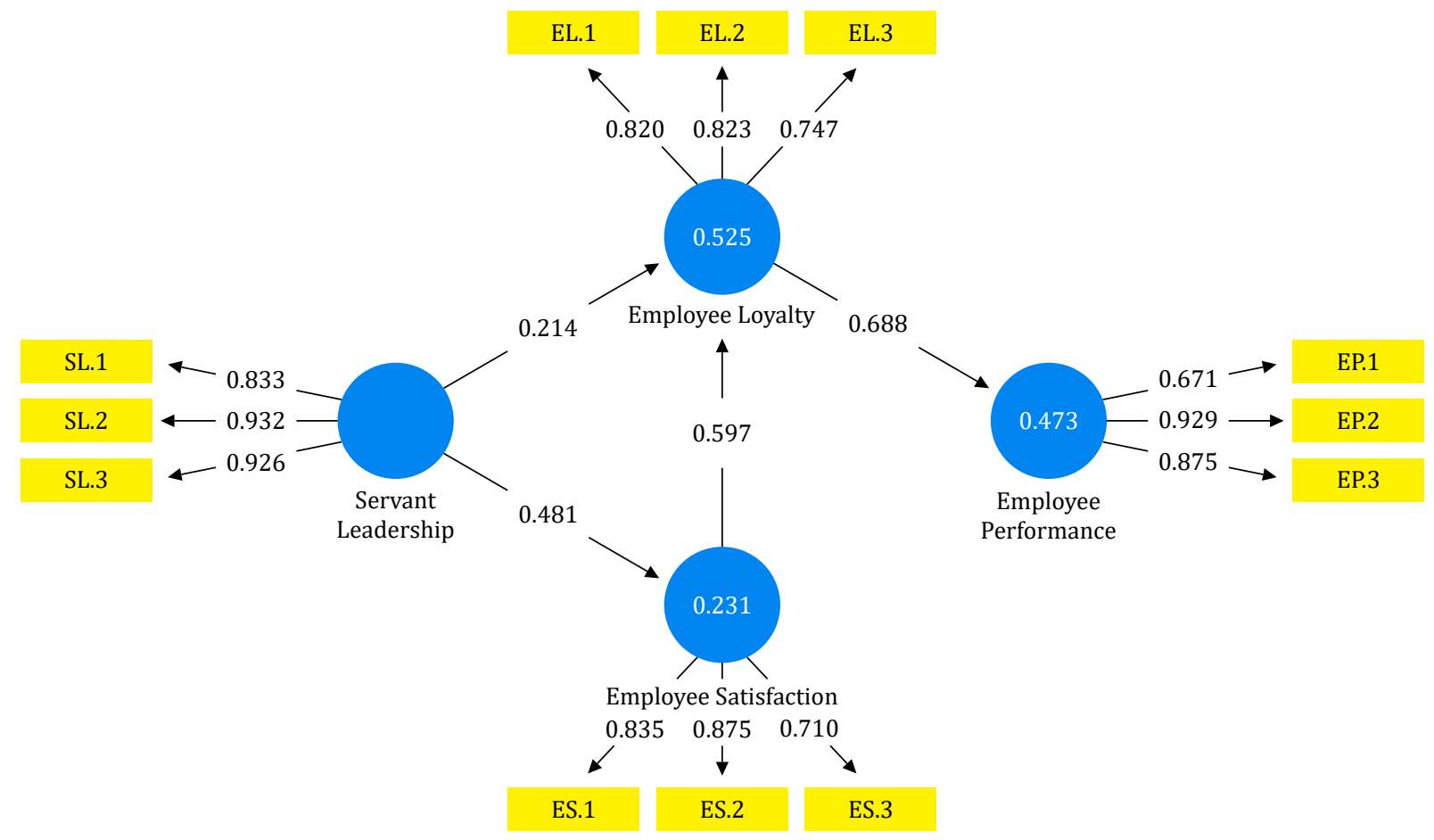

Figure 3. Coefficient Correlation Diagram 


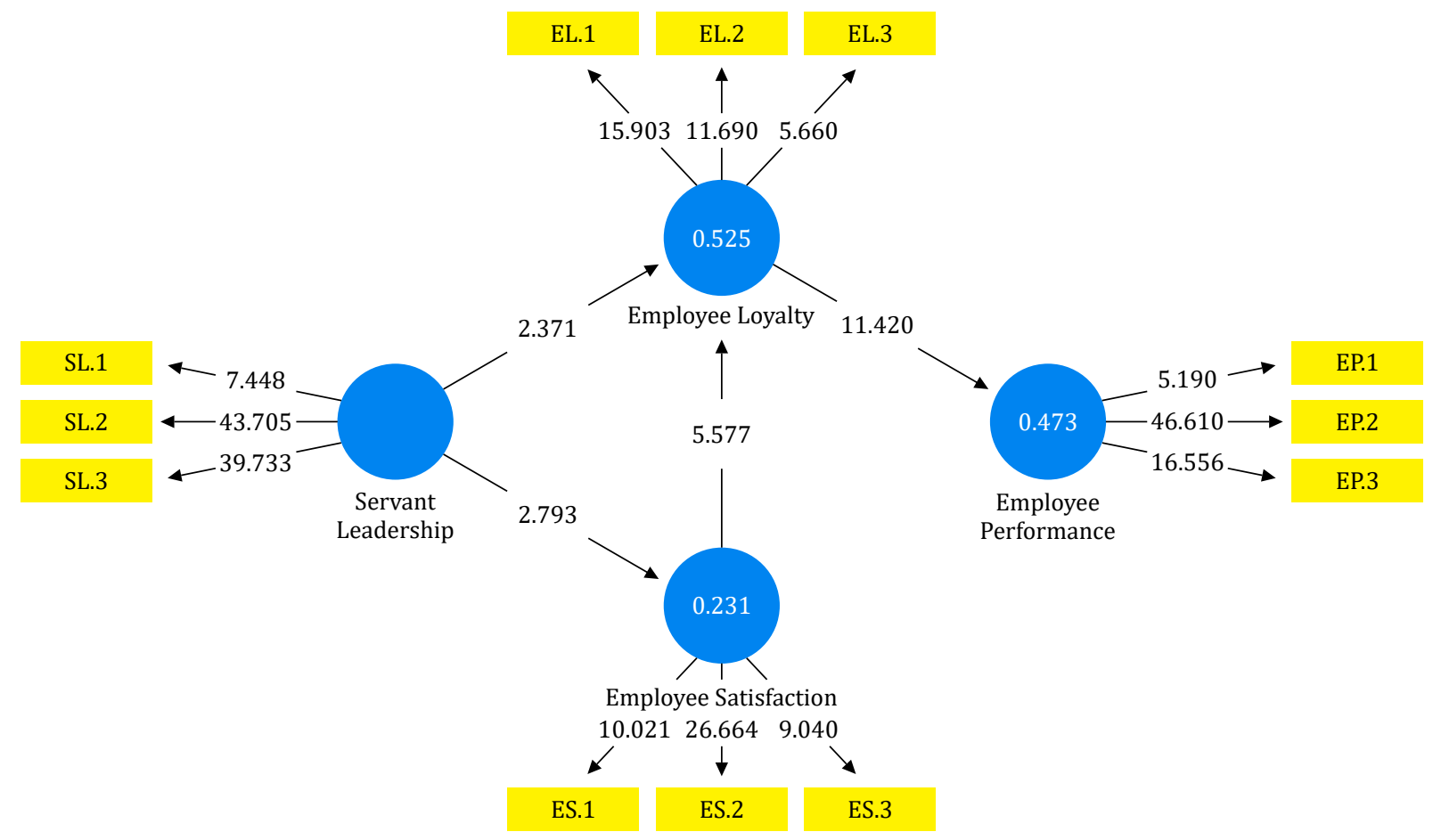

Figure 4. Significance diagram

Table 6. Path Coefficient

\begin{tabular}{lcccc}
\hline Variables & Coefficient & T- Statistics & P-Value & Result \\
\hline $\begin{array}{l}\text { Servant Leadership } \rightarrow \\
\text { Employee Loyalty }\end{array}$ & 0,214 & 2,371 & 0,018 & Supported \\
\hline $\begin{array}{l}\text { Servant Leadership } \rightarrow \\
\text { Employee Satisfaction }\end{array}$ & 0,481 & 2,793 & 0,005 & Supported \\
\hline $\begin{array}{l}\text { Employee Satisfaction } \rightarrow \\
\text { Employee Loyalty }\end{array}$ & 0,597 & 5,577 & 0,000 & Supported \\
\hline $\begin{array}{l}\text { Employee Loyalty } \rightarrow \\
\text { Employee Performance }\end{array}$ & 0,688 & 11,420 & 0,000 & Supported \\
\hline
\end{tabular}

\section{Hypothesis Result}

Hypothesis that have been previously established need to be evaluated. The hypothesis needs to be evaluated whether the variable is significant or not. By using the PLS program and the bootstrapping procedure, original sample value, t-statistic, and p-value will be collected. It is considered as significant if the t-statistic is higher than $1.96 \%$ at the $5 \%$ error margin level (Ghozali, 2014).

There are two indicators of hypothesis testing measured in this research, T-test and P-Value, as showed in Table 6 above.

From the above Table, this research supports the four hypothesis. Firstly, the hypothesis proposed that servant leadership has a positive impact on employee loyalty. The result shown that original sample value is 0.214 (positive), t-statistic is $2.371(>1.96)$ and $p$-value is $0.018(<0.05)$. Therefore, hypothesis is accepted. Means that servant leadership has positive impact on employee loyalty. The better the servant leadership, the higher the employee loyalty of Garuda Motor. Secondly, the hypothesis proposed that servant leadership has a positive impact on employee satisfaction. The result shown that original sample value is 0.481 (positive), t-statistic is $2.793(>1.96)$ and p-value is $0.018(<0.005)$. Therefore, hypothesis is accepted. Means that servant leadership has positive impact on employee satisfaction. The better the servant leadership, the higher the employee satisfaction 
of Garuda Motor. Thirdly, the hypothesis proposed that employee satisfaction has a positive impact on employee loyalty. The result shown that original sample value is 0.597 (positive), t-statistic is $5.577(>1.96)$ and p-value is $0.000(<0.05)$. Therefore, hypothesis is accepted. Means that employee satisfaction has positive impact on employee loyalty. The better the employee satisfaction, the higher the employee loyalty of Garuda Motor. Finally, the hypothesis proposed that employee loyalty has a positive impact on employee performance. The result shown that original sample value is 0.688 (positive), t-statistic is $11.420(>1.96)$ and $p$-value is $0.000 \quad(<0.05)$. Therefore, hypothesis is accepted. Means that employee loyalty has positive impact on employee performance. The better the employee loyalty, the higher the employee performance of Garuda Motor.

\section{DISCUSSION}

In the first hypothesis, it is said that servant leadership has a positive impact on employee loyalty. From the whole series of tests that have been carried out, the results are obtained that the first hypothesis is accepted. This is consistent with what Jaramillo et al. (2009) stated that servant leadership will increase employee adaptability to the place of work and will further increase employee loyalty. This is also supported by the statement of Ding et al. (2012) in his study that servant leadership will have a positive effect on employee loyalty and ultimately reduce employee turnover levels. Hashim (2014) also expressed that servant leadership influences employee loyalty. Employees will increase their loyalty as they adapt to their work environment, this is due to the pattern of leader's behavior serving their employees.

No contrary statement said by Liden et al. (2008), servant leadership will create a positive working environment and as conditions employees feel comfortable and result in employee loyalty. From those, it can be concluded that the result of first hypothesis is accepted and has no contrary result to the previous research used in this study.
For the second hypothesis it is said that servant leadership has a positive impact on employee satisfaction. From the whole series of tests that have been carried out, the results are obtained that the hypothesis is accepted. Weiss (2004) concluded that servant leadership focuses on aspects of employee needs, emotions, and happiness. Therefore, servant leadership will affect employee happiness and satisfaction. Another statement was also expressed by Benligiray (2004) which states that servant leadership directly influences employee satisfaction toward employee performance to achieve company goals.

In a study in India, Jenkins \& Stewart (2008) revealed that the higher the services provided by leaders, the more satisfaction received by employees. In line with this, Mehta \& Pillay (2011) stated that servant leadership has a positive influence on employee satisfaction. From those, it can be concluded that the result of second hypothesis is accepted and has no contrary result to the previous research used in this study.

In the third hypothesis it is said that employee satisfaction has a positive impact on employee loyalty. From the whole series of tests that have been done, the results are obtained that the hypothesis is accepted. There are two perspectives measured by Tang Yao et al. (2008) related to employee satisfaction and employee loyalty. The first perspective is that employees will tend to stay at the company instead of having to move to another place where the risk cannot be measured. The second perspective is that employees will give positive energy if they feel comfortable in their company. In this case it can be concluded that if employees feel satisfied then they will tend to keep working in their current place.

The same conclusion was expressed by several researchers in their study results (Chow et al., 2007; Falkenburg \& Schyns, 2007; Alfonso \& Sousa-Poza, 2007). The study shows when employee satisfaction is low, the turnover rate increases. From those, it can be concluded that the result of third hypothesis is accepted and has 
no contrary result to the previous research used in this study.

In the fourth hypothesis it is said that employee loyalty has a positive impact on employee performance. From the whole series of tests that have been done, the results are obtained that the hypothesis is accepted.

Niehoff et al. (2001) defined loyalty as "active behaviors that demonstrate pride in and support for the organization". Defending the organization against criticism, emphasizing the positive aspects of the organization, and refraining from complaining about the organization would be examples of such behaviors. In this case it is concluded that loyal employees will make many contributions to the company. In line with these results, O'Reilly and Chatman (1986) stated that a loyal employee will contribute to the company and help the company to run more efficiently. From those, it can be concluded that the result of fourth hypothesis is accepted and has no contrary result to the previous research used in this study.

\section{CONCLUSION}

Firstly, there is positive impact of Servant Leadership to Employee Loyalty and Employee Satisfaction. First and second hypothesis accepted, thus servant leadership proven to have positive impact both on the employee loyalty and employee satisfaction. The higher the servant leadership shows by the leader, the higher positive impact on employee loyalty and employee satisfaction.

Secondly, there is positive impact of Employee Loyalty to Employee Performance. Fourth hypothesis accepted, thus employee loyalty proven to have positive impact on the employee performance. Means that the higher the employee loyalty, the employee's performance will increase also.

Thirdly, there is positive impact of Employee Satisfaction to Employee Loyalty. Third hypothesis accepted, thus employee satisfaction proven to have positive impact on the employee loyalty. Once employee satisfies, accordingly improve employee loyalty to the company.

Theoretically, after going through a series of analysis, it was found that the study of the three previous variables, namely servant leadership, employee loyalty, and employee satisfaction give impact through employee loyalty can have a positive effect on employee performance. Practically, the results of this study can be used to increase the level of the variables measured in this study. Increased servant leadership will directly affect employee loyalty and employee satisfaction, and will later increase employee performance to achieve the company's goals that have been targeted.

This research has limitation where the samples are limited to the employee of Garuda Motor which may causes the limitation of particular company and amount of the samples and does not measures the impact of employee satisfaction to employee performance. As for future research, there are several recommendations which are: (1) recommend to use other variables such as decision making, employee morale, organizational culture, innovation, work motivation, and many more; (2) to enlarge the scale of the population taken to be able to broaden the scope of research results; (3) to examine the reverse effects of each of the existing variables whether the results are positive or negative.

There are also several recommendations related to the organization which are: (1) servant leadership is one of the leadership styles that is suitable to be applied which is proven to have a positive influence on employee loyalty and employee satisfaction; (2) leaders to measure the level of servant leadership using indicators that have been used in this study; (3) to determine the level of needs of existing employees as one of the parameters to improve employee satisfaction which will have a positive effect on employee loyalty. 


\section{REFEREN CES}

Adams, J. S. (1965). Inequity in social exchange. In L. Berkowitz (Ed.), Advances in experimental psychology (pp. 267-299). New York: Academic Press.

Alfonso, S. and Sousa-Poza, Andres. (2007). The effect of job satisfaction on labor turnover by gender: An analysis for Switzerland. Journal of Socio-Economics, 3(6), 859-913. https://doi.org/10.1016/ j.socec.2007.01.022.

Arghode, V. (2012). Qualitative and quantitative research: Paradigmatic differences. Global Education Journal, 2012(4), 155-163.

Benligiray, S. (2004). Human resources management. Turkey: Eskisehir Anadolu University.

Chee C., Haddad K., \& Singh G. (2007). Human resources management, job satisfaction, morale, optimism and turnover. International Journal of Hospitality and Tourism Administration, 8(2), 73-88.

Davis, J.A. (2014). Managing the Family Business: Leadership Roles. Harvard Business School, retrieved 3 October 2019 from https://hbswk.hbs.edu/item/managing-the-family-business-leadershiproles

Dierendonck, Van D. (2011). Servant leadership: A review and synthesis. Journal of Management, 37(4), 1228-1261. https://doi.org/10.1177/0149206310380462.

Ding, D., Lu, H., Song, Y., \& Lu, Q. (2012). Relationship of servant leadership and employee loyalty: The mediating role of employee satisfaction. iBusiness Scientific Research, 4(20), 8-215.

Ehrhart, M. G. (2004). Leadership and procedural justice climate as antecedents of unit-level organizational citizenship behavior. Personnel Psychology, 57(1), 24-84. https://doi.org/10.1111/j.17446570.2004.tb02484.x.

Falkenburg, K., \& Schyns, B. (2007). Work satisfaction, organizational commitment and withdrawal behaviours. Management Research News, 30(10), 708-723. https://doi.org/ 10.1108/01409170710823430.

Ghozali, I. (2014). Structural equation modeling metode alternatif dengan PLS (edisi 4). Semarang: Badan Penerbit Universitas Diponegoro.

Gomes, Faustino Cardoso. (2001). Manajemen sumber daya manusia. Yogyakarta: BPFE.

Greenleaf, R. K. (1979). Servant leadership: A journey into the nature of legitimate power and greatness. New York, NY: Paulist Press.

Hagan, T. L. (2014). Measurements in quantitative research: How to select and report on research instruments. Oncology Nursing Forum, 41(4), 431-433. https://doi.org/10.1188/14.0NF.

Hale, J. R., \& Fields, D. L. (2007). Exploring servant leadership across cultures: A study of followers in Ghana and the USA. Leadership, 3(4), 397-417. https://doi.org/10.1177/1742715007082964.

Hashim, M. (2014). Organizational change: Case study of GM (General Motor). Open Journal of Industrial and Business Management, 2(2), 001-005. https://doi.org/10.12966/ojibm.05.03.2014.

Herujito, Y. M. (2001). Dasar dasar manajemen. Jakarta: PT. Grasindo.

Herzberg, F., Mausner, B., \& Snyderman, B. B. (1993). The motivation to work. New York: Wiley \& Sons.

Jaramillo, F., Grisaffe, D., Chonko, L., \& Roberts, J. (2009). Examining the impact of servant leadership on salesperson's turnover intention. Journal of Personal Selling and Sales Management, 29(4), 351365. https://doi.org/10.2753/PSS0885-3134290404.

Jenkins, M., \& Stewart, A. C. (2008). Enhancing nurse job satisfaction: The importance of a servant leader orientation in health care management. Academy of Management 2008 Annual Meeting: The Questions We Ask, 1-6. A0M 2008.

Laub, J. A. (1999). Assessing the servant organization: Development of the Servant Organizational Leadership (SOLA) instrument. Dissertation Abstracts International. 60(2), 308 (UMI No. 9921922). 
Willy B. Wibowo, Risa Bhinekawati / The Impact of Servant Leadership on Employee Performance Mediated by Employee Loyalty and Employee Satisfaction: A Case Study of PT. Garuda Totalindo Jaya / 18 - 31

Liden, R. C., Wayne, S. J., Zhao, H., \& Henderson, D. (2008). Servant leadership: Development of a multidimensional measure and multi-level assessment. Leadership Quarterly, 19(2), 161-177. https://doi.org/10.1016/j.leaqua.2008.01.006.

Locke, E. A. (1976). The nature and causes of job satisfaction. Handbook of Industrial and Organizational Psychology (pp 1297-349). Chicago, IL: Rand McNally.

Mangkunegara, A. P. (2005). Manajemen sumber daya manusia perusahaan. Bandung: PT. Remaja Posdakary.

Martin, A. D. (2000). Kompetensi model, tren baru re-vitalisasi SDM. Jakarta: PT Refika Aditama.

Masrukhin, S., \& Waridin, A. (2006). Pengaruh motivasi kerja, kepuasan kerja, budaya organisasi, dan kepemimpinan terhadap kinerja pegawai. Ekobis.

Mehta, S., \& Pillay, R. (2011). Revisiting servant leadership : An empirical in Indian context. The Journal Contemporary Management Research, 5(2), 24-41.

Niehoff, B. P., Truitt, M. R., Moorman, R. H., Daugherty, R. B., Blakely, G., \& Fuller, J. (2001). The Influence of empowerment and Job enrichment on employee Loyalty in a downsizing environment. Group and Organization Management, 26(1), 93-113. https://doi.org/10.1177/1059601101261006.

Nguyen, Thi Ngoc Diem. (2016). The factors affecting employee's satisfaction and loyalty: an evidence from the people's committee of binh tan district, Ho Chi Minh City. Vietnam: University of Tampere.

O’Reilly, C., \& Chatman, J. (1986). Organizational commitment and psychological attachment: The effects of compliance, identification, and internalization on prosocial behavior. Journal of Applied Psychology, 71(3), 492-499. https://doi.org/10.1037/0021-9010.71.3.492.

Pandey C., \& Khare, R. (2012). Impact of job satisfaction and organizational commitment on employee loyalty. International Journal of Social Science \& Interdisciplinary Research, 1 (8), 26-41.

PWC. (2018). Family business survey-2018. https://www.pwc.com/id/en/epc/fbs-2018-indonesia.pdf. Rasimin, B. S. (1998). Manusia dalam industri dan organisasi. Yogyakarta: Universitas Gadjah Mada.

Reichheld, F., \& Teal, T. (1996). The loyalty effect. Business Ethics Quarterly. Retrieved from http:// www.getcited.org/pub/103351260.

Rivai, V. (2006). Kepemimpinan dan perilaku organisasi. Jakarta: PT. Raja Grafindo Persada.

Sendjaya, S., \& Sarros, J. C. (2002). Servant leadership: its origin, development, and application inorganizations. Journal of Leadership and Organization Studies. 57-64.

Setyaningrum, P.R., Setiawan, Margono, \& Surahman. (2017). Organizational commitments are mediation of relationship between servant leadership and employee performance. Journal of Applied Management. 693-701. http://dx.doi.org/10.21776/ub.jam.2017.015.04.17.

Siagian, S. P. (2003). Manajemen sumber daya manusia (Cetakan XI). Jakarta: PT. Bumi Aksara.

Silalahi, U. (2009). Metode penelitian sosial. Jakarta: PT. Refika Aditama.

Simamora, H. (1995). Manajemen sumber daya manusia. Yogyakarta: STIE YKPN.

Siswanto, B. (2003). Manajemen tenaga kerja, rancangan dalam pendayagunaan dan pengembangan unsur tenaga kerja. Bandung: Penerbit Sinar Baru.

Steers, R. M., \& Porter, R. W. (1983). Motivation and work behavior. New York: Mc Graw Hill.

Tang Yao, W., Huang, B., \& Fan, X. C. (2008). Research about employee loyalty of the services sector based on the organizational commitment mechanism. Management World Magazine. Vol. 5. pp 102-123.

Vroom, V. H. (1964). Work and motivation. New York: Wiley.

Wang, C, X., Ling, Q., \& Zhang, X. J. (2009). The servant leadership scale design and inspection in chinese enterprise. Nankai Business Review. 3. 94-103.

Weiss, W. (2004). Team management. Supervision. 65(11). 19-24.

Yukl, G. (2006). Leadership in Organisations (6th ed). New Jersey: Prentice Hall. 